\title{
The Prospects for Legislative Modeling "Smart Government" in Political and Legal Realities of Russia
}

\author{
Arthur G. Kravchenko \\ Svetlana F. Litvinova \\ Vladivostok State University of Economics and Service \\ Email: eldirect@mail.ru,kravchenko_artur@mail.ru
}

Doi:10.5901/mjss.2015.v6n3p341

\begin{abstract}
The article is devoted to the problem of the current establishment and further development of democratic, legal, progressive model of government, based on a fundamentally new approaches to the modelling of the state administration of Russia, the Russian bureaucracy and building of powerful communications through the application of information and communication technologies. Thus, the subject of the research is a new global trend of "smart government", including the latest global trends in the development of E-Government and the formation of a fundamentally new form of bureaucracy. The author gives a critical evaluation model of E-Government, played by Russian legislation and the system of official electronic resources of Russia, reveals the national peculiarities of the state traditions of public administration, the archetypal features of the Russian bureaucracy, indicating the level of viability of the project "E-Government" in the context of clashes with the real political and legal practices, analyze the latter, highlighting key legislative and infrastructural achievements and problems of the system organization of electronic forms of government communications with which the current IT reform by the Russian government is dealing. In concluding the article, the authors formulate the key findings of the study, the prospects for legislative modeling and development of "smart government" in the world and the Russian Federation.
\end{abstract}

Keywords: E-Government, information and communication technologies, bureaucracy, state archetypes, smart government.

\section{Introduction}

Today one of the global problems of mankind is the question of finding the optimal model of state administration, which could provide the most rationally constructed processes of public management in the economic, political, legal, cultural, social and other spheres of society life. Regardless of the national characteristics of models of bureaucracy and public administration system, a society where economic, technological, cultural and spiritual development is a priority goal (L. Kirsanova and O. Korotina, 2014), politicians and lawyers strive to design and develop a completely new model of public management, in the key properties of which "genetic code" of administrative optimality and bureaucratic rationality is placed. Finally, the latest world trends show that the number of states enter the third phase of the formation of the architecture of the E-Government, called smart government. Based on the content of research in recent years, this stage involves the creation of a fully interactive government that meets the requirements of mobility, openness, full electronic availability of participatory mechanisms of interaction between society and the (S. Melloulia et al., http:/liospress. metapress.com/content/x0921055457568t0, 2014).

Meanwhile, in the Genesis of the "ideal" state, there are two main problem areas for countries in the first stages of E-Government institutions. First, this is generation and the introduction of fundamentally new technological tools in the public administration system. In this sense, the processes of formation and development of E-Government are associated with the technological development of societies, the development of the global information space, new technological means of communication, digital literacy, society and bureaucracy. Accordingly, in this plane problem of our study is the legislative innovations, introducing in the practice of states with the new tools of public communications. Second, a more fundamental problem for Russia is the architecture of the model of state power, which traditionally tends to be of authoritarian structure of public administration, patrimonial system of interaction between state, society and irrational bureaucracy. However, it should be noted that the state apparatus itself acting in the cultural archetypal national field is shorted to the need of finding an effective political and legal controls of the Russian society. The latter in its turn leads to the impossibility of implementing successful Western model of the state in its pure form (A. Mamychev, 2014). For example, all states, where historically stable authoritarian political systems were formed, are characterized by the absence of systemic self-organization of national societies, at simultaneous archetypes of a "strong state" and "ward 
society". At the same time, the social matrix of social relations in Russian society is bind mainly by system of informal (shadow) links, creating a dual reality, where one of them form official state institutions, their legal status and legal processes of public administration. The second reality, hidden from the outside observer, is not immersed in the context of real political and social practices reality, is alternative to legal field and public policy. As a result of a significant development of corruption phenomenon, that Russian for society adopts a more narrow meaning than for Western European and American models of interaction between the personality of the state (T. Yudina, 2012), reducing corruption to bribery, at simultaneously discharging a lot of informal communications, not persecuted by law only due to the limitation of the regulatory formulas of the national legal system.

Also this is national-usual socio-illegal behavior at the household levels - from obtaining medical services introduction to informal requests between superior and subordinate in a commercial or public institutions.

A significant role in the choice models of social behavior lying within the field of legal regulators has public views about justice, good and evil.

Accordingly, in a situation of conflict between social values and legal field, the priority is often given to the first.

Meanwhile, such axiological priorities make legislation unstable and arbitrarily applied and approved by the regulator. Public faith in government as the most effective form of organization of society that displays quasi public institutions and shadow sliders in the predominant form of social communication are not a characteristic of Russia. It is obvious that such an objective national-cultural conditions force the state to resort to authoritarian methods of individual management and to shorten to themselves the greater part of public functions, which in Western societies is traditionally in the public self-regulation. Hence the difficulties of held IT reforms, aroused not only due to systemic corruption and bureaucratization of the state apparatus, but also the natural state of society itself that must be considered at the legislative implementation of E-Government institutions.

\section{Literature Review}

Giving a description of the scientific elaboration of the theme of our article, it should be noted that considered problematic issues are associated with certain theoretical contradictions and practical problems. Thus, in various scientific sources, the term "Smart government" is understood rather broad and does not have an unambiguous interpretation. Western European researchers understand this term with the highest level of E-Government development (Melloulia et al., http://iospress.metapress.com/content/x0921055457568t0, 2014), and many Russian scientists generally do not share these concepts, which probably explains the very limited amount of scientific literature devoted to this subject . Meanwhile, there is the third point of view on the trend of "smart government" as a special system of electronic communications between the authorities and society, providing intelligent, fully interactive mode of interaction of the authorities, the authorities of society, government business (Hassan et al., http://d.researchbib.com/f/, 2014). However, it is obvious that the concept of "smart government" is at the stage of formation which is also fair for IT architectures of the most advanced countries in the field of information and legal regulation of information relations. The second problem addressed in Russian scientific journals is a range of problems in the implementation stages of the genesis of EGovernment. Here such scientists as: (O. Astafiev and V. Savinkov, 2013; and E. Dyakova, 2014) illustrate in their works problems of regional development of information communications of public authorities, legal regulation of computerized procedures, digital rights and responsibilities of citizens and officials, an interim legislative measures on the operation of the digital infrastructure of the government. Cultural and archetypical phenomena reflecting national identity of formation and development of the Russian state is investigated in the scientific article of Mamichev (A. Mamichev, 2014). Threats to network forms of organization of state power and society are discussed in the article of (A. Ovchinnikov, 2014).

\section{Methods and Materials}

Theoretical and methodological basis of research of article is based on universal, scientific, special and specific scientific methods. Among the general methods, used in the study for analysis of state legal reality, the following can be distinguished: a systematic approach, dialectic-materialistic method, phenomenological and hermeneutic method.

In addition, in the work comparative legal, historical legal, specifically sociological and formal-legal (dogmatic) methods, and methods of political-legal modeling required for the formulation of the forecast of the further institutional development of the technologies of E-Government were used. The materials for research of the article became the scientific literature, normative acts regulating public relations in the field of public administration, the empirical basis consisted of: judicial practice, official sources of statistical data (rating of UN), social surveys of the Foundation of public opinion. 


\section{Results and Discussion}

However, the legal policy of the Russian state held a course for the architecture of the "E-Government" and therefore the task is to establish the legal, political and administrative conditions of the electronic transit of state communications to the modern forms. In this regard, the President of the Russian Federation, the Parliament of the Russian Federation and the Government of the Russian Federation developed and put into force a set of conceptual and provisional regulations, which in their turn reflected regional authorities. It is noteworthy that, despite the pronounced centralized nature of the Russian Federation, some regional legislative initiatives ahead on development the legislative base and innovative elements of IT services of the system of Federal state control system. Thus, in particular the Moscow region has made significant progress in the systemic organization of technological chains of provision of public services to the population.

If we consider the legislative novels of recent years highlighting the most significant normative acts on the formation of elements of the infrastructure of E-Government can be identified according to the relevant branches of government the following:

1. In the sphere of the concept of E-Government - Federal law dated 06.04.2011 \# 63-FL (edit. from 28.06.2014) "On electronic signature"; Decree of the President of the Russian Federation dated 21.08.2012 \# 1202 (edit. from 25.07.2014) "On approval of the Regulations of the President of the Russian Federation on the application of information technology and the development of E-Democracy; Regulation of the RF Government dated 25.04.2012 \# 394 "On measures to improve the use of information and communication technologies in the activities of state bodies"; the Federal law of 27.07.2006 \# 149-FL (edit. from 21.07.2014) "On information, information technologies and protection of information; Resolution of the Government of the Russian Federation from 15.04.2014 \# 313 (edit. from 21.02.2015) "On approval of the state program of the Russian Federation "Information society (2011-2020)".

2. In the formation of electronic and mobile justice - resolution of the Government of the Russian Federation of 27.12.2012 \# 1406 (edit. from 25.12.2014) "On the Federal target program "development of the judicial system of Russia for 2013 - 2020 years" including regulating the establishment and operation of electronic archives of litigation and remote access to them.

3. In the sphere of formation of the electronic infrastructure of the executive authorities of the Russian Federation Government dated on September 22, 2009 \# 754 "On approval of the Regulations on the system of interdepartmental electronic document"; the Decree of the RF Government dated 08.09.2010 \# 697 (edit. from 05.12.2014) On the common system of interdepartmental electronic interaction" (along with "Regulation on the unified systems of interdepartmental electronic interaction).

4. In the sphere of provision of public services - Federal law dated 27.07.2010 \# 210-FL (edit. from 31.12.2014) "On the organization of public and municipal services".

5. In the field of organization of E-Democracy - the Federal law dated 10.01.2003 \# 20-FL (edit. from 12.03.2014) "On the State automated system of the Russian Federation "Elections".

6. In the sphere of public control over the activities of public authorities - the Federal law from 21.07.2014 \# 212FL "On fundamentals of social control in the Russian Federation".

Of course specified regulatory framework, uniting under itself more than hundreds of normative acts, governing digital forms of organization and functioning of public authorities is by no means perfect, including normative acts are regulatory fragmentary, partly not agreed among themselves. But somehow, in the last three years, it should be recognized that IT reform entered the second phase, and a separate electronic tools of bureaucracy began to take shape in the system model of E-Government (E. Dyakova, 2012). This also is reflected in legislation and the creation of appropriate E-infrastructures enabling the participation of citizens in planning of laws, the evaluation of activity of bodies of state power, remote access to a wide range of public services. In fact, Russia has moved to the planning of open government, which eventually should ensure full transparency of the activities of public institutions, with some exceptions.

However, the rate of introduction of IT technologies in the system of state control of Russia is still far behind the global dynamics. If to assess the level of development of the first and second stages of the formation of e-Government at the moment under the current law and a functioning of IT infrastructure, Russia ranks 27 th place in the ranking of UN among the leading E-Governments of the world and for the last 2 years its position is not strengthened (E-Government Development Index, 2014). From our point of view, assessment methodology of UN does not allow to capture the true state of affairs of Russian reality, because domestic bureaucracy has deep historical tradition and experience in imitation of successful activity. From this point of view no matter whether we talk about Khrushchev reports about "harvest of corn", "Potemkin villages" or the creation of IT infrastructure technologies in the system of state institutions. In Russia the presence of formally established institutions and infrastructures of E-Government does not mean their effective 
functioning, and this peculiarity the researchers of UN apparently do not take into account.

The second flaw of assessment methods of development of national E-Government architectures of UN of world level is putting an equal sign between the level of development of IT technologies and the development of democratic and legal institutions of the state. In this regard, it should be noted that "E-Government" itself is only an effective technological tool of public administration, and does not mean a guarantee of playback of democratic values and ideas of the legal state. Thus, assessing high-tech from the point of view of information-communication technologies in the government of Singapore, rather we can talk about playing "model of law (police) state" that differs from the "legal state" by absence of real recognition and protection of the rights and freedoms of the individual in the legal field, but a high level of adherence to the law in society and developed legal technology. The government does not meet also the common Western standards of democracy. In this sense, a little bit strange are rating and assessment methodologies of UN of development of national models of E-Government where Singapore is ranked 3rd in the world index e-Government (in our opinion here is the myth of democracy of E-Government which is " by default" in tune with the myth of the strong economies only in democratic countries, in recent cases, in recent cases as examples can be used China's authoritarian political regime). Essentially, however, these indices only take into account technological tools, reproduced by states, avoiding the evaluation of paradigm maintenance of systems of public administration. As a consequence of this a general understanding of the concept of "electronic government" is distorted, reducing it to purely technological means of administrative work.

Meanwhile, contemplated by the Europeans a fundamental difference in the models of E-Governments has such significant meaning as the distinction between law-abiding Nazi Germany and any modern European country. After all, in both cases the level of law and order has had a significant level, with the only difference that in the Nazi political regime generally accepted rights and freedoms did not admit and was not guaranteed.

In this context, critically evaluating the ongoing transformation of legal fields and the creation, practice of operation of certain digital items of "E-Government" in Russia should be paid attention to several key problems, which do not let the current model of the Russian state transfer to democratic model of "E-Government". So, for example, electronic means have been used by the bureaucracy in direct analogy with the "paper", "oral" form of communication, often reproducing all the same architecture irrational bureaucracy. As a consequence paper replies were replaced by electronic, without any efficiency gains. Simultaneously, there was a new "effective" instrument of the traditional bureaucracy, for example, the facts of violation of the terms or facts to the lack of public services are justified by electronic systems failures (A. Didikin, 2013).

A major stumbling block in the advancement of E-Government became gaps of technological chains in the system of government communications, in which the subjects of public relations only at certain stages resort to electronic forms of interaction. This is certainly makes easier in some cases the work of state institutions and citizens ' efforts to obtain public services, but does not solve the fundamentally important tasks assigned to IT by the reform of the Russian state. In particular, such tasks as anti-corruption environment of public communications, de-bureaucratization of the official procedures and processes, interactivity (feedback) of state authorities, public accountability of state and municipal institutions remain partially achievable. It is obvious that the existence of such practices in the transition to electronic forms of interaction itself does not create conditions for the rationalization of the Russian bureaucracy, does not provide optimal algorithms of functioning of systems of public administration, it is initially assumed in the concept of egovernment. On the contrary, facing with national sustainable cultural archetypes in the public administration, borrowed from Western examples models of progressive institutions of E-Governments are either limited or distorted, changing its purpose in the service of corruption, bureaucratic or political interests. A serious obstacle to the expansion of the IT infrastructure in the state management system is the high level of information inequality, although judging by the findings of the public opinion Foundation, the percentage of active involvement of citizens in the Internet technology is growing steadily and as for 2014 it was 51\% of respondents (The public opinion Foundation, http://fom.ru/SMI-i-internet/11889, 2014). However, a serious problem in the development of digital communications experience remote from cities, rural settlements, which presents a considerable part of the population. Even fewer people use in their daily life the electronic communication when interacting with state and municipal institutions, such in 2012, according to public opinion Foundation was about 68\% (The public opinion Foundation, http://fom.ru/SMI-i-internet/10850, 2012). Here social surveys of the public opinion Foundation show the real picture of the involvement of Russian society in the processes of functioning of E-Government and indicate the magnitude of the digital divide (A. Didikin, 2013). The digital divide in its turn correlates with the traditional socio-political passivity of the Russian population that actually paralyzed the initiative of the Government of the Russian Federation on carrying out participatory mechanisms, which means the organization of a network of state and interactivity of power in the interaction with society (Y. Kayl and V. Epinina, 2012).

Of course, not all the reasons for the delay in the development of E-Government are called by the national 
peculiarities of the Russian mentality and established a stable system of illegal relations contrary by its nature openness of the information society. Not solved remain technological issues, including the provision of digital security. Both social and expert fears, that weak protection of network communications may be subject to distortion of the will of the citizens, digital fraud, with spoofing identity of personality, finally, concerns that civil rights may be part of a network attack, have not grou ndless basis. (A. Ovchinnikova, 2014).

Meanwhile, the above allows to conclude that for Russia the completion of the second stage in the formation of EGovernment and the transition to its third - system-final stage is the most important and fundamental question ( $O$. Astafiev and V. Savinkov, 2013). Let us argue that without going to the level of smart government, IT reforms will only create an effective bureaucratic elements, but will not resolve such key public problems such as bureaucracy, corruption and politicization of administrative procedures and judicial processes.

\section{Conclusion}

Thus, summarizing our research, it is important to stop on the key findings and conclusions of the prospects for legislative modeling of "smart government" in political and legal realities of Russia and world trends:

1. By the beginning of 2015 in the system of Russian legislation were introduced key institutions of the egovernment sector in providing of public services. At the same time legitimized elements of "service government" is not provided with electronic forms of legal safeguard of the rights of citizens and organizations, the system of electronic communications inter-regional and nationwide level is not established. And regional public service systems are predominantly local in nature.

2. The subsystem of "e-government" - E- democracy, is in initial development, and its most promising elements, including electronic voting is under question due to the concerns of both citizens and representatives of public authorities in terms of providing digital security.

3. The introduction of digital technologies in the system of state management is still very low. The system of Eplanning, control of electronic communications between the public authorities is under development and staging deployments. Accordingly, the legislative framework is overly abstract, does not contain detailed legal regulators of electronic forms of interaction between public authorities, the use of electronic systems of mass surveillance and so on. The latter aspect is only to legislatively formulate legal boundaries between public safety and personal rights.

4. Today, the Russian Federation reproduces a patrimonial system of government based on irrational bureaucratic model. Thus, the use of electronic communications can contribute to the transformation of traditional systems of public management in Russia only with unconditional playback of continuity of the whole technological chain of e-governance, meeting the requirements of transparency, public accountability, availability of legal protection of the legitimate interests of the individual.

5. The latest world tendencies of the leaders of the introduction of IT technologies in the public administration system suggest the emergence of new forms of government communications, but also the transformation of the rational bureaucracy in an online form. However, the latter is formed in states not only with the advanced architecture of e-government, undergoing the stage of formation of smart government, but also meeting the standards of democracy, legal state and internationally recognized human rights and freedoms.

6. Under the conceptual plan for "smart government" should be understood systematically completed version of "e-government" that meet criteria such as: public openness, accessibility, interactivity, technological and legal security. Thus, "Smart government" is based on the network architecture of the state authorities, consistent with the principles of democracy and unconditional compliance, the higher priority of human rights and freedoms, and safety of society.

7. Smart government is expressed in forms of mobile accessibility, full electronic identification and electronic forms of communication with state institutions. Interactivity of "smart government" includes qualified to provide information to the consumer of public services at all levels, legal and public protection of the person directly in electronic communications, accountability of public institutions public institutions and the political and administrative practices of the intellectual potential of the society in socially significant questions(smart citizen).

8. The nearest international perspectives in the field of scientific research and development of the concept of "smart government" is a simulation of the system of state administration, responsible for global forms of rights and freedoms not because of his nationality and area of residence The trend to create a single electronic interstate space within the European Union and the United States is obvious. It is not excluded that after this the formation of a regional system in the developed countries in the Eastern part of the world: South Korea, 
Japan, Singapore, etc. will take place.

\section{References}

Astafiev, O. and Savinkov V., 2013. Russia's way to the information society: perspectives on open government in the context of modernization ideas. Eurasian integration: Economics, law, politics, (13), pp. 234-243.

The public opinion Foundation, 2012. Retrieved March 11, 2015. http://fom.ru/SMI-i-internet/10850

Didikin, A., 2013. Open government in the mechanism of interaction between civil society and state: the formation of the legal model and its contradictions. Civil society in Russia and abroad (1), pp. 16-19.

Dyakova, E., 2012. The evolution of E-government as a regulatory concept: from the provision of services to an open government. Novosibirsk state University. Series: philosophy, (3), pp. 134-138.

E-Government Development Index, 2014. Retrieved March 11, 2015. http://unpan3.un.org/egovkb/en-us/Data-Center

Kirsanova, L., Korotina O., 2014. On the Contents of the Protest Conscience in Russia. Wolrd Applied Sciences Journal 31(5): 930-934.

Hassan, I., Mahdi A. and Al-Khafaji N., 2014. Theoretical study to highlight the smart government components in 21st century. International Journal of Computer Science and Mobile Computing, 3(12), pp. 333-347. http://d.researchbib.com/f/8nnJcwp21wYz AioF9x02AmY3OupTIIpI9RMJAyoJWypwVjZGDilwAWZGVIZQROBGyuZF5jMTL.pdf.

Kayl, Y. and Epinina V., 2012. Update participatory approach to the formation of public power system in modern Russia. National interests: priorities and security. (33), pp. 57-63.

Mamychev, A., 2014. State power in the XXI century: contemporary political projects of the simulation. State power and local selfgovernment (1), pp. 3-9.

Melloulia, S., Luna-Reyes L. and Zhang J., 2014. Smart government, citizen participation and open data. Information Polity, 19(1-2), 1-4. http://iospress.metapress.com/content/x0921055457568to/fulltext.pdf.

Dynamics of penetration. Autumn, 2014. The public opinion Foundation. http://fom.ru/SMI-i-internet/11889.

Ovchinnikova, A., 2014. Russia's national security in a networked war. Philosophy of law, (2), pp.97-99.

Yudina, T., 2012. The national information infrastructure for open government in the USA and Canada. USA and Canada: Economics, politics, culture, (9), pp. 86-105. 